\title{
DAMPAK KETIDAKPUASAN KONSUMEN PADA SIKAP KONSUMEN BERDASARKAN DIMENSI KUALITAS JASA DAN PERBEDAAN KARAKTERISTIK DEMOGRAFI
}

\section{IMPACT OF CONSUMER DISSATISFACTION ON CONSUMER ATTITUDES BASED ON SERVICE QUALITY DIMENSIONS AND DEMOGRAPHIC CHARACTERISTICS DIFFERENCES}

\author{
Anis Hidayah \\ Fakultas Ekonomi Jurusan Manajemen Universitas Mercu buana Yogyakarta \\ Email: anis hidayah@yahoo.co.id

\section{Sumiyarsih} \\ Fakultas Ekonomi Jurusan Manajemen Universitas Mercu buana Yogyakarta \\ Email: sumiyarsih@mercubuana-yogya.ac.id
}

\begin{abstract}
ABSTRAK
Tujuan makalah ini adalah untuk menguji pengaruh ketidakpuasan konsumen yang berpengaruh terhadap perilaku pelanggan negatif, berdasarkan demografi dan kualitas layanan. Desain / metodologi / pendekatan, Model terpadu yang diusulkan, mengikuti perkembangan terakhir dalam literatur pemulihan layanan. Model ini diuji dengan menggunakan data dari survei dengan 216 pelanggan. Laporan kertas hasil dari model aquasi struktural. Temuan, hasilnya menunjukkan pengaruh yang signifikan terhadap kualitas layanan, demografi dan ketidakpuasan pelanggan berpengaruh signifikan terhadap perilaku pelanggan negatif.
\end{abstract}

Kata kunci: ketidakpuasan pelanggan, perilaku pelanggan, demografi dan kualitas layanan.

\begin{abstract}
The purpose of this paper is to test the effect of dissatisfaction consumers that influence on negative customer behavior, base on demography and service quality. Design/methodology/approach, An integrated model is proposed, following recent developments in the service recovery literature. This model is tested using data from a survey with 216 customers. The paper reports results from structural aquation model. Findings, the results show significant influence service quality, demography and dissatisfaction customer have significant effect to negative customer behavior.
\end{abstract}

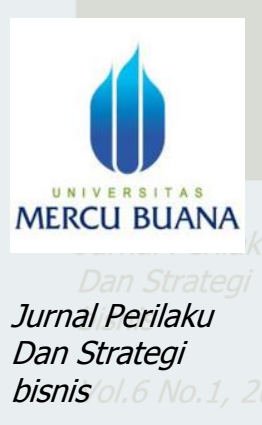

Vol.6 No.1, 2018

Hal. $47-57$

Keyword: dissatisfaction customers, customer behavior, demography and service quality.

\section{PENDAHULUAN}

Telekomunikasi adalah teknik pengiriman atau penyampaian infomasi, dari suatu tempat ke tempat lain. Telekomunikasi berkembang pesat setelah ditemukan transistor, Integrated Circuit (IC), sistem prosesor, dan sistem penyimpanan. Media komunikasi kini 
menjadi kebutuhan atau bahkan gaya hidup bagi masyarakat. Setiap karakter masyarakat memiliki keinginan dan kepentingan informasi yang berbeda - beda untuk memenuhi kebutuhannya, sehingga dapat dimanfaatkan sebagai bahan segmantasi pasar serta menentukan dimensi kualitas produk atau jasa yang akan mereka beli. Telekomunikasi seluler secara umum dapat diartikan sebagai bagian dari perkembangan teknologi komunikasi. Dalam aplikasinya, beberapa pengguna atau pelanggan kartu seluler tidak puas terhadap kinerja seluler yang mereka gunakan. Pada saat seseorang tidak puas banyak cara atau tindakan yang mereka ambil, seperti diam saja, melakukan negatif word of mouth atau menceritakan pengalamannya kepada orang lain, complain langsung kepada perusahaan operator, berpindah pada merek kartu seluler lain atau bahkan mengambil tindakan hukum. Pemasaran memiliki peranan penting dalam pengenalan serta mempertahankan produknya, seperti iklan pengenalan produk, promo atau penawaran fitur baru untuk pengguna kartu seluler. Perkembangan teknologi komunikasi mendorong berkembangnya perusahaan jasa layanan operator telekomunikasi seluler yang menawarkan keunggulannya masing - masing, sehingga tak heran jika terjadi persaingan yang cukup ketat pada industry telekomunikasi jaringan operator di Indonesia.

Definisi pemasaran menurut Kotler (1993) dapat dijelaskan sebagai berikut: "Pemasaran adalah proses sosial dan manajerial dengan mana seorang atau kelompok memperoleh apa yang mereka butuhkan dan inginkan melalui penciptaan pertukaran produk dan nilai. Konsep pemasaran ini di dasarkan pada konsep - konsep inti berikut ini yaitu kebutuhan, keinginan dan permintaan, periodik, utilitas, nilai dan kepuasan, tranaksi, dan hubungan, pasar, pemasaran dan pasaran". Menurut teori tersebut, dapat dikatakan bahwa pemasaran harus berorientasi pada kepuasan konsumen. Terjadinya ketidakpuasan konsumen dikarenakan pembeli atau pengguna merasakan ketidaksesuaian antara kinerja produk dengan keinginan dan kebutuhan yang mereka harapkan terhadap produk, sehingga mendorong mereka untuk meresponnya melalui sikap, baik sikap yang positif maupun yang negatif terhadap produk atau perusahaan. Produk telekomunikasi seluler merupakan produk yang terbentuk atas loyalitas konsumennya terhadap perusahaan. Salah satu yang menjadi alasan bagi seorang konsumen untuk tetap bertahan pada kartu telekomunikasi seluler yang digunakan adalah karena nomor kartu selulernya telah dikenal oleh banyak orang serta kepuasan terhadap provider atau peusahaan operator.

\section{TINJAUAN PUSTAKA DAN PENGEMBANGAN HIPOTESIS Definisi Dimensi Kualutas Pelayanan}

Service quality atau kualitas pelayanan adalah penilaian konsumen tentang kehandalan dan superioritas pelayanan secara keseluruhan (Zeithaml, Berry, dan Parasuraman, 1998). Konsumen akan membuat perbandingan antara yang mereka berikan dengan apa yang mereka dapatkan (Bloemer et al, 1998). Secara umum kualitas pelayanan merupakan faktor untuk menciptakan profitabilitas dan sukses perusahaan (Aydin dan Ozer, 2005 dalam Karsono 2008). Jaminan, kehandalan, empati dan tangibles dimensi kualitas layanan adalah prediktor kepuasan pelanggan di Siprus sektor perbankan (Jamal, 2007). Baumann et al. (2007) menemukan bahwa semua dimensi, kecuali tangibility berdampak pada kepuasan pelanggan perbankan Australia. Selanjutnya, karena sifatnya pelayanan tidak berwujud, seringkali sulit bagi pelanggan untuk memahami dan mengevaluasi layanan, jadi pelanggan membuat kesimpulan tentang kualitas layanan pada dasar tangibles yaitu seperti bangunan, peralatan, tata letak fisik yang mengelilingi lingkungan layanan (Jane Li et al, 2010).

\section{Definisi Kepuasan}

Kepuasan adalah perasaan senang atau kecewa seseorang yang muncul setelah membandingkan kinerja (hasil) produk yang dipikirkan terhadap kinerja atau hasil yang 
diharapkan. Jika kinerja di bawah harapan maka pelanggan akan tidak puas. Jika kinerja memenuhi harapan harapan maka pelanggan puas, dan jika kinerja melebihi harapan maka pelanggan sangat puas atau senang (Kotler, 2008).

Kepuasan menggambarkan derajat dimana seorang konsumen percaya untuk menggunakan sebuah pelayanan atau jasa dan membangkitkan rasa positif saat menggunakannya (Jane $\mathrm{Li}$ et al, 2010). Kepuasan adalah reaksi emosional yang dirasakan oleh pelanggan dengan membandingkan antara harapan dan evaluasi kinerja (Oliver, 1980, 1997; Yi, 1990). Jika kecewa, emosi negatif seperti rasa frustrasi, penyesalan, dan kemarahan akan mereka alami (Bonifield dan Cole, 2007). Sedangkan beberapa pelanggan mencoba untuk mendapatkan bantuan untuk melampiaskannya dengan mengomentari layanan (Sundaram et al, 1998; Wetzer et al, 2007) dengan tujuan untuk mencari pembalasan dan atau meperingatkan orang lain tentang penyedia layanan (Anderson, 1998 dalam Swanson et. al, 2011).

\section{Demografi}

Demografi terdiri dari jenis kelamin, usia, tingkat pendidikan, tingkat pekerjaan, tingkat pendapatan, ukuran keluarga, siklus hidup keluarga, agama, ras, generasi, kewarganegaraan, dan kelas social. Variabel demografi, merupakan dasar untuk membedakan kelompok - kelompok pelanggan. Salah satu alasannya adalah perbedaan keinginan, kebutuhan, preferensi atau kesukaan dan frekuensi tingkat pemakaian masing masing konsumen terhadap produk dan jasa juga berbeda - beda (Kotler, 2008).

Umur adalah variabel demografis yang secara luas digunakan untuk mengkarakterisasi adopsi teknologi antara dua atau lebih kelompok konsumen (Morris dan Venkatesh dalam Kumar dan Lim, 2008). Konsumen yang memiliki usia lebih tua mengendalikan lebih dari $50 \%$ dari pendapatan diskresioner, sehingga membuat para pengecer ingin menarik dan memuaskan segmen pasar tersebut (Salomo dalam Dean,2008) Penelitian sebelumnya yang dilakukan oleh Heung dan Lam (2003) dan Kau et al. (1995) yang keduanya menemukan bahwa wanita lebih banyak memilih untuk mengeluh dari pada lakilaki (Phau. I, dan Baird. M, 2008).

Perilaku keluhan berhubungan terbalik dengan usia, dan positif terkait dengan pendapatan dan pendidikan (Heung dan Lam, 2003). Variabel demografi lain dipandang sebagai outlier, jenis kelamin misalnya, dan lokasi tempat tinggal antara pedesaan atau perkotaan kecenderungan untuk mengeluh (Boote, 1998), status perkawinan tunggal dikaitkan dengan masalah dengan kartu kredit (Hogarth et al, 2001a., b), dan status perkawinan berulang tidak ada hubungannya dengan kepuasan (Broadbridge dan Marshall, 1995 dalam Phau. I dan Baird. M, 2008).

\section{Sikap}

Sikap adalah suatu kecenderungan yang dipelajari untuk bereaksi terhadap penawaran produk dalam masalah - masalah yang baik ataupun kurang baik secara konsekuen" (Swastha dan Handoko, 1984). Reaksi paling umum dari insiden kritis negatif konsumen, yaitu tidak aktif atau diam saja, sebagai akibat perilaku non mengeluh. Beberapa studi melaporkan bahwa dua pertiga dari pelanggan gagal untuk laporan ketidakpuasan mereka kepada perusahaan, hal itu dikarenakan kemungkinan besar dari mereka yang tidak mengeluh hanya untuk memutuskanhubungan atau dengan kata lain berhenti menggunakan pelayanan dari perusahaan dengan meninggalkan perusahaan (Ladhari, 2009). Hari dan Landon (1977) menyebutkan 2 tingkat hirarki dimana tindakan tingkat dibedakan dalam dua tingkat yaitu dari pribadi dengan tindakan word of mouth komunikasi kepada teman - teman dan keluarga dan atau berhenti untuk merendahkan outlet ritel dengan, dan dari publik yaitu dengan tindakan mencari ganti rugi atau 
pengembalian uang dari penjual, mengeluh kepada organisasi konsumen dan tindakan hukum (Tronvollm, 2011).

\section{PENGEMBANGAN HIPOTESIS}

\section{Pengaruh Dimensi Kehandalan Terhadap Ketidakpuasan Konsumen}

Kehandalan yaitu kemampuan perusahaan untuk memberikan pelayanan sesuai yang dijanjikan secara akurat dan terpercaya. Kinerja harus sesuai dengan harapan pelanggan yang berarti ketepatan waktu, pelayanan yang sama untuk semua pelanggan tanpa kesalahan, sikap yang simpatik dan dengan akurasi yang tinggi. Jika kinerja memenuhi harapan maka pelanggan puas jika kinerja tidak memenuhi harapan maka konsumen tidak puas.

H1: Kehandalan berpengaruh positif terhadap ketidakpuasan konsumen.

\section{Pengaruh Jaminan Terhadap Ketidakpuasan Konsumen}

Jaminan dan kepastian yaitu pengetahuan, kesopansantunan dan kemampuan para pegawai perusahaan untuk menumbuhkan rasa percaya para pelanggan kepada perusahaan. Terdiri dari beberapa komponen, antara lain komunikasi, kredibilitas, keamanan, kompetensi dan sopan santun. Kepercayaan terhadap perusahaan merupakan indikasi bahwa konsumen puas terhadap kinerja perusahaan.

$\mathrm{H} 2$ : Jaminan kualitas berpengaruh positif terhadap ketidakpuasan konsumen

\section{Pengaruh Daya Tanggap Terhadap Ketidakpuasan Konsumen}

Ketanggapan, yaitu suatu kemauan untuk membantu dan memberikan pelayanan yang cepat (responsive) dan tepat kepada pelanggan, dengan penyampaian informasi yang jelas. Membiarkan konsumen menunggu tanpa adanya alasan yang jelas menyebabkan persepsi yang negatif dalam kualitas pelayanan. Daya tanggap penyedia jasa yang baik dapat meningkatkan kepuasan konsumen.

H3 : Daya tanggap berpengaruh positif terhadap ketidakpuasan konsumen

Pengaruh Usia pada ketidakpuasan konsumen terhadap sikap konsumen Umur adalah variabel demografis yang secara luas digunakan untuk mengkarakterisasi adopsi teknologi antara dua atau lebih kelompok konsumen. Keinginan dan kemampuan konsumen berubah sejalan dengan bertambahnya usia.

$\mathrm{H} 4$ : Usia berpengeruh positif pada ketidakpuasan konsumen terhadap sikap konsumen Pengaruh jenis kelamin pada ketidakpuasan konsumen terhadap sikap konsumen Jenis kelamin yaitu pria dan wanita, keduanya memiliki orientasi sikap dan perilaku yang berbeda yang didasarkan pada genetic dan praktik sosialisasi. Wanita cenderung memperhatikan kebersamaan dan pria cenderung mengambil lebih banyak data di lingkungan dekat mereka H5 : Jenis kelamin berpengaruh positif pada ketidakpuasan konsumen terhadap sikap konsumen

Pengaruh tingkat pekerjaan pada ketidakpuasan terhadap sikap konsumen Pekerjaan sangat berhubungan erat dengan tingkat penghasilan, sehingga bempengaruhi tingkat kemampuan seseorang dalam melakukan pembelian terhadap suatu penawaran produk dan jasa. Shukla et al.,(2004) kelas sosial sulit untuk menentukan berdasarkan pendapatan. Perilaku pembelian dalam sosial kelas terkait dengan kondisi budaya, lokasi, sumber pendapatan dan sampai batas tertentu pendidikan dan pekerjaan (Beldona dan Mundhra, 2010)

H6 : tingkat pekerjaan pengguna berpengaruh positif terhadap ketidakpuasan konsumen Pengaruh tingkat pendidikan pada ketidakpuasan terhadap sikap konsumen Populasi dalam masyarakat mana saja terbagi ke dalam lima kelompok pendidikan yaitu buta huruf, tidak lulus SMA, lulus SMA, lulus perguruan tinggi dan lulus profesi. Semakin tinggi jumlah kaum terpelajar di suatu negara maka semakin tinggi permintaan atas buku, teknologi, majalah dan perjalanan yang bermutu tinggi serta tinggi pula penawaran keahlian. 
H7 : Tingkat pendidikan berpengaruh positif pada ketidakpuasan konsumen terhadap sikap konsumen

\section{Pengaruh ketidakpuasan terhadap sikap diam saja}

Sikap terhadap mengeluh, dan kecenderungan untuk mengeluh merupakan pembeda antara karakteristik antara kedua kelompok, dan variasi konsumen yang lain adalah kecenderungan untuk mencari ganti rugi. Dengan kata lain, beberapa orang yang bersemangat untuk mengeluh dan kembali produk gagal sementara yang lain menunda untuk mengembalikan produk cacat atau hanya membenci ide mengeluh.

H8 : Ketidakpuasan konsumen berpengaruh positif pada sikap diam saja

\section{Pengaruh ketidakpuasan terhadap sikap negatif word of mouth}

Pelanggan dapat memilih untuk menyuarakan keluhan kepada penjual atau pada pihak ketiga tergantung pada tingkat loyalitas pelanggan. Hari dan Landon (1977) menyebutkan dua tingkat hirarki di mana tindakan tingkat pertama dibedakan dari non aksi dan tingkat kedua dibedakan pribadi yaitu dengan tindakan word of mouth yaitu mengkomunikasikan pengalaman dalam menggunakan produk kepada teman-teman dan keluarga dan atau berhenti untuk merendahkan outlet ritel.

H9 : Ketidakpuasan konsumen berpengaruh positif terhadap sikap word of mouth

\section{Pengaruh ketidakpuasan terhadap sikap complain ke perusahaan}

Ketidakpuasan disampaikan secara langsung ke penyedia layanan adalah usaha untuk memulihkan perusahaan dari kegagalan. Kegagalan perusahaan dimulai dari pengalaman konsumen dalam menggunakan produk biasa pada saat mencoba atau bahkan terjadi berulang-ulang selama konsumen menggunakan produk barang maupun jasa.

H10 : Ketidakpuasan Konsumen berpengaruh positif terhadap sikap complain pada perusahaan

\section{Pengaruh ketidakpuasan terhadap sikap tindakan hukum}

Emosi adalah konsep kunci menjelaskan pasca pemulihan loyalitas dalam rangka memperoleh manfaat dari loyalitas pelanggan terus menerus. Loyalitas terbentuk karena adanya sikap konsumen. Tindakan yang dilakukan oleh konsumen atas pengalamannya dapat dilakukan dengan pihak ketiga, misalnya dengan mengambil tindakan hukum atau mengeluh kepada pihak ketiga eksternal.

H11 : ketidakpuasan konsumen berpengaruh positi terhadap sikap mengambil jalur hukum untuk mendapatkan haknya.

\section{KERANGKA PEMIKIRAN}

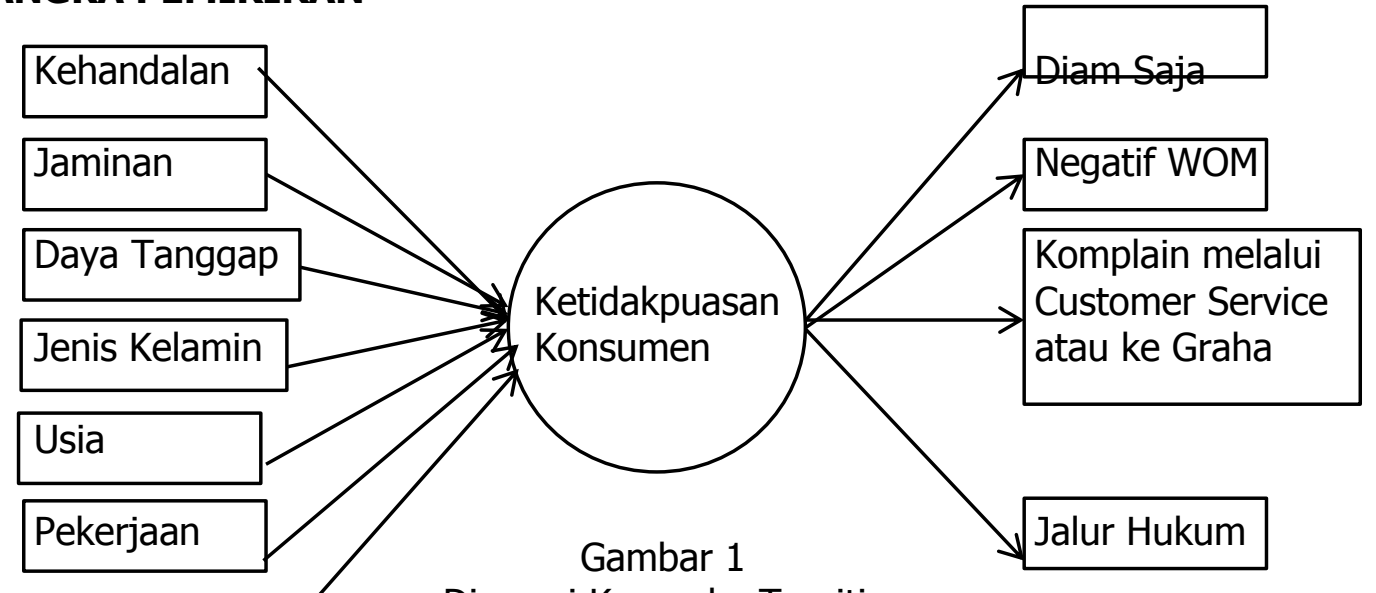

Pendidikan

Dimensi Kerangka Teoritis 


\section{METODE PENELITIAN}

Penelitian ini menggunakan Structural Equation Modelling sebagai alat pengujian hipotesis, dengan melibatkan 216 masyarakat yang tinggal di Yogyakarta pengguna jasa layanan operator telekomunikasi seluler yang diambil melalui penyebaran kuesioner yang diadopsi dari Rod (2009), Sandy (2011), Edgar dan Fuchs (2009), Neira (2010), Matos (2009), Syarma et. al (2009), Faiswal dan Niraj (2011) dengan dibagikan secara langsung serta e - mail dan pesan melalui facebook. Teknik sampling yang digunakan dalam penelitian ini adalah accidental sampling. Skala pengukuran dalam penelitian ini menggunakan Skala Likert jenjang 5 (Sangat Setuju - Sangat Tidak Setuju).

\section{HASIL D}

Usia responden 15 - 24 tahun berjumlah 145 orang, yang berusia 25 - 34 tahun sebanyak 53 orang, 35 - 44 tahun sebanyak 14 orang, 45 - 54 tahun 3 orang dan yang berusia 55 - 64 tahun sebanyak 1 orang. Responden yang berjenis kelamin laki - laki berjumlah 111 orang dan perempuan 105 orang. Status pekerjaan responden sebagai pelajar atau mahasiswa sebanyak 94 orang, PNS 5 orang, karyawan swasta 107 orang, sebagai pengusaha 5 orang dan yang tidak bekerja sebanyak 5 orang. Sedangkan karakteristik pendidikan responden yang berpendidikan SMP sebanyak 2 orang, SMA atau SMK sebanyak 124 orang dan yang berpendidikan setara dengan Perguruan Tinggi sebanyak 90 orang.

Sikap konsumen yang sering dilakukan oleh konsumen adalah sikap negatif word of mouth yaitu dengan menceritakan pengalaman ketidakpuasan kepada kerabat dan teman. Sedangkan sikap tindakan jalur hukum tidak menjadi pilihan yang terlebih dahulu dilakukan karena menurut wawancara, banyak responden yang menyatakan bahwa tindakan jalur hukum merupakan tindakan yang sia - sia, berlebihan dan akan membutuhkan biaya yang cukup banyak.

Hipotesis keempat menyatakan bahwa terdapat pengaruh usia pada ketidakpuasan konsumen terhadap sikap konsumen, berdasarkan hasil distribusi frekuensi menunjukkan bahwa, usia konsumen yang berada di bawah 34 tahun lebih cenderung setuju dan senang terhadap sikap mengeluh, maka hipotesis diterima.

Hipotesis kelima menyatakan bahwa terdapat pengaruh jenis kelamin pada ketidakpuasan konsumen terhadap sikap konsumen, yang ditunjukkan dengan wanita lebih cenderung senang menyampaikan keluhan setelah mengalami ketidakpuasan, dibandingkan dengan laki - laki sehingga hipotesa diterima.

Hipotesa keenam menyatakan bahwa, terdapat pengaruh pekerjaan pada ketidakpuasan konsumen terhadap sikap konsumen, pada penelitian ini menunjukkan bahwa responden yang berstatus sebagai karyawan swasta cenderung suka dengan sikap complain baik melalui layanan customer service maupun graha resmi, sedangkan yang berstatus sebagai pelajar dan mahasiswa lebih cenderung senang terlibat dalam negatif word of mouth dan complain melalui layanan customer service, sehingga hipotesa diterima.

Hipotesa ketujuh menyatakan bahwa, terdapat pengaruh pendidikan pada ketidakpuasan konsumen terhadap sikap konsumen, dengan hasil penelitian bahwa responden yang berpendidikan SMP menyatakan tidak setuju dengan sikap tindakan jalur hukum,responden yang berpendidikan SMA atau SMK lebih senang dengan sikap negatif word of moth dan complain melalui customer service, sedangkan responden yang berpendidikan setara dengan Perguruan Tinggi cenderung senang dengan sikap complain dan beberapa setuju dengan sikap tindakan hukum, maka hipotesa 7 diterima.

Hasil uji resbilitas dan validitas menunjukkan bahwa terdapat 2 item petanyaan yang tidak valid namun reliabel, yaitu pada pertanyan tentang sikap diam saja dan negatif word of mouth, dengan nilai Corrected Item-Total Correlation -0,034 dan 0,02, nilai tersebut lebi kecil dari nilai Table Nilai $r$ Product Moment yaitu pada jumlah responden 216 dengan taraf 
signifikan $5 \%$ sehingga terletak pada nilai 0,138 . Sehingga, kedua item tersebut harus didrop dan tidak dapat dilakukan pengujian selanjutnya.

Nilai critical skewness (kemencengan) pada penelitian ini nilainya lebih kecil dari 2,58 yaitu daya tanggap 0,973; jaminan -2,161; kehandalan 0,522, jalur hukum 1,403; complain melalui graha resmi atau service center sebesar -4,198; dan complain melalui layanan customer service sebesar $-4,811$. Sehingga dapat disimpulkan bahwa, variabel penelitian ini terdistribusi secara normal, karena nilai critical skewwness lebih kecil dari 2,58 secara univariate. Secara multivariate nilai 6,909 merupakan koefisien dari multivariate kurtosis, dengan nilai critical 5,182, sehingga data terdistribusi normal secara multivariate, karena nilainya tidak jauh dari 2,58.

Hasil uji Mahalobis d - square yaitu mengukur jarak skor hasil observasi terhadap nilai centroidnya terdapat 2 data yang outlier, jumlah data yang outlier tersebut jumlahnya tidak lebih dari 5\% dari jumlah keseluruhan responden yaitu 5\% dikali dengan 216 kasus sama dengan 10,8 , sehingga kedua data tersebut tidak perlu didrop.

Uji signifikansi probabilitas dapat ditunjukkan dengan kehandalan terhadap ketidakpuasan, jaminan terhadap ketidakpuasan dan daya tanggap terhadap ketidakpuasan memiliki nilai estimate 1, ketiganya nilai probabilitasnya tidak muncul, hal ini dapat dianggap, bahwa nilai signifikansi probabilitasnya adalah signifikan pada 0,01 atau $1 \%$.

Sedangkan pada ketidakpuasan terhadap complain melalui layanan customer service memiliki nilai probabilitas sebesar 0,011 sehingga dapat dikatakan bahwa tingkat probabilitasnya adalah sangat signifikan pada 0,01 atau 1\%, pada ketidakpuasan terhadap complain melalui layanan graha resmi yang disediakan oleh provider operator seluler nilainya sebesar 0,003 , dapat diartikan bahwa signifikan pada 0,01 atau $1 \%$. Ketidakpuasan terhadap jalur hukum memiliki nilai 0,016, yang dapat diartikan bahwa nilai probabilitasnya signifikan pada 0,01 atau $1 \%$. Berdasarkan penjelasan tersebut dapat disimpulkan bahwa hipotesa $\mathrm{H} 1, \mathrm{H} 2, \mathrm{H} 3, \mathrm{H} 10$, dan H11diterima.

Hasil nilai means dan intercept dari model yang digunakan, dengan nilai intercept 1 pada keidakpuasan, 3,529 pada complain1 yaitu melalui customer service, 3,195 pada complain2 yaitu complain melalui graha resmi dan 2,524 pada jalurhk yaitu tindakan jalur hukum. Sehingga dapat diperoleh model persamaan regresi sebagai betikut :

Ketidakpuasan $\quad=1+1$ kehandalan +1 jaminan +1 dayatanggap

Complain $1 \quad=3,529+0,061$ ketidakpuasan

Complain2 $\quad=3,195+0,078$ ketidakpuasan Jalurhk $\quad=2,525+0,033$ ketidakpuasan

Menilai kriteria Goodness of fit yaitu menilai kelayakan dari model struktural apakah data yang diolah memenuhi asumsi model persamaan struktural atau tidak. Nilai NFI adalah 0,95 atau 95\%, sehingga dapat dikatakan bahwa model sangat fit. Nilai TLI menunjukkan angka 0,945 sehingga dapat disimpulkan analisis faktor telah memenuhi dengan sangat baik.

Nilai CMIN/DF pada penelitian ini adalah 2,295, sehingga dapat dikatakan bahwa model fit. Sedangkan nilai RMSEA menunjukkan angka 0,078, sehingga dapat dikatakan bahwa model sangat baik.

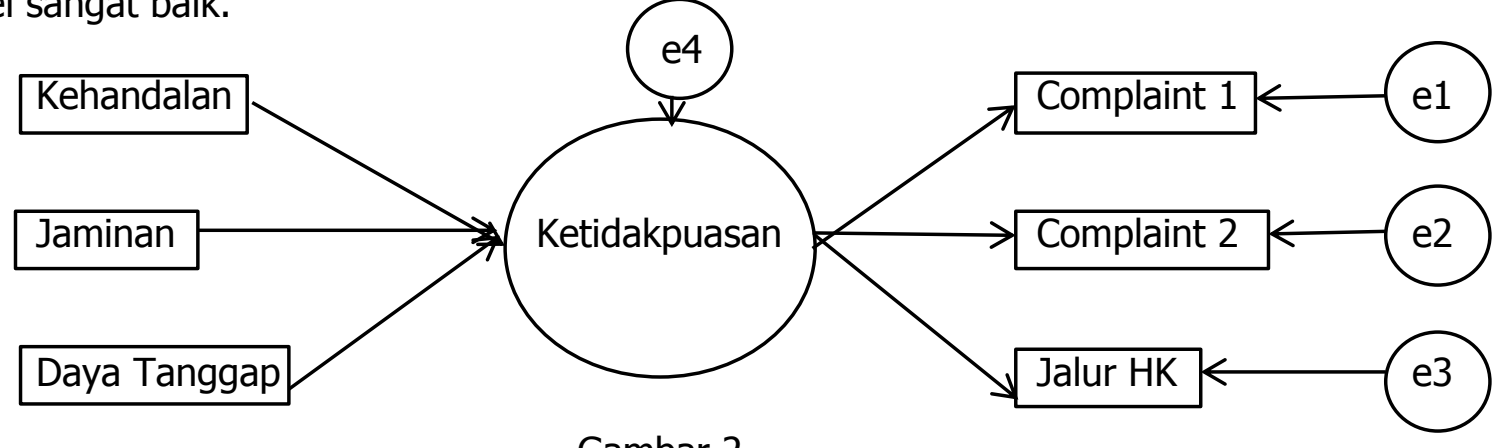

Gambar 2

Final Model 


\section{REKOMENDASI HASIL PENELITIAN UNTUK PENELITIAN YANG AKAN DATANG}

Berdasarkan hasil analisis dan pembahasan tentang dampak ketidakpuasan terhadap sikap konsumen berdasarkan karakteristik konsumen dan dimensi kualitas pelayanan, maka dapat diberikan saran sebagai berikut :

1. Penelitia ini kurang memberikan data yang spesifik mengenai letak tempat tinggal responden, sehingga tidak dapat menjelaskan ketidakpuasan konsumen terhadap kehandalan jangkauan sinyal. Karena, jangkauan sinyal berhubungan erat dengan kondisi geografis tempat tinggal dan perbedaan antara pengguna layanan yang bertempat tinggal di kota dengan pengguna yang tinggal di desa.

2. Penelitian ini juga kurang spesifik dalam menjelaskan atau menyebutkan nama provider atau penyedia jasa layanan konsumen, sehingga tidak dapat menjelaskan secara terperinci provider layanan operator seluler manakah yang memberikan kehandalan, jaminan, dan daya tanggap yang terbaik hingga yang tidak baik.

3. Terdapat 2 variabel yang tidak valid yaitu variabel sikap diam saja dan melakukan negatif word of mouth dengan menyampaikan poin pertanyaan yang lebih banyak an terperinci mengenai sikap diam saja dan negatif word of mouth, sehingga perlu dilakukan penelitian lanjutan agar kedua variabel tersebut dapat diketahui hubungannya dengan ketidakpuasan.

4. Pada pertanyaan opsional pilihan jawaban sebaiknya tidak berupa mengurutkan sikap negatif pasca ketidakpuasan, akan tetapi secara konsisten ditegaskan hanya memilih salah satu jawaban yang jelas akan dilakukan oleh konsumen. Sehingga tidak terjadi pilihan yang tidak konsisten sperti pilihan yang sudah melakukan tindakan kemudian berbalik memilih yang tidak melakukan apapun seperti diam saja.

5. Pada penelitian selanjutnya dapat ditambahkan dimensi kualitas layanan lainnya seperti dimensi tangibel atau bukti nyata seperti layanan sarana dan prasarana dalam bentuk fisik dari graha resmi yang disediakan dan emphaty dari karyawan garis depan dari provider operator seluler dalam menanggapi keluhan dan menyelesaikan masalah ketidakpuasan yang telah dirasakan oleh konsumennya. Serta menambahkan karakteristik responden seperti tempat tinggal atau daerah asal.

6. Penelitian selanjutnya dapat menambahkan variabel sikap negatif akibat ketidakpuasan konsumen, yaitu sikap berpindah pada provider lain atau ganti ke provider layanan operator telekomunikasi seluler lain.

7. Pada penelitian selanjutnya juga dapat dilakukan pada segmen karakteristik responden tertentu misalkan saja pada responden yang berstatus sebagai pelajar, mahasiswa saja atau yang bekerja saja.

8. Penelitian selanjutnya dapat menambahkan variabel sikap setelah mengalami ketidakpuasan konsumen yaitu sikap meninggalkan perusahaan atau berpindah ke provider layanan telekomunikasi seluler lain untuk mendapatkan produk yang sesuai dengan keinginan dan kebutuhannya.

9. Penelitian ini diharapkan dapat memberikan masukkan kepada sebagian provider penyedia layanan operator jasa secara luas, mengenai kebijakan yang perlu diambil tentang dampak ketidakpuasan konsumen terhadap sikap konsumen berdasarkan dimensi kulaitas jasa dan karakteristik responden, serta diperlukan evaluasi terhadap harga atau tarif layanan, agar konsumen dapat lebih puas dan tercipta loyalitas pelanggan yang dapat dilakukan dengan meningkatkan kinerja pada layanan customer service dan graha resmi.

\section{DAFTAR PUSTAKA}

Beldona. S, Moreo. A. P, dan Mundhra G. S., Research In Brief The Role Of Involvement And Variety-Seeking In Eating Out Behaviors International Journal Of Contemporary Hospitality Management, Vol. 22, No. 3, 2010 pp. 433 - 444. 
Dean. D.H., 2008 Shopper Age And The Use Of Self-Service Technologies Managing ServiceQuality, Vol. 18 , No. 3, pp. $225-238$

Ekiz. E. H dan Au.N, 2011, Comparing Chinese And American Attitudes Towards Complaining, International Journal Of Contemporary Hospitality Management, Vol. 23 No. 3, pp. $327-343$

Etgar. M dan Fuchs. G., 2009, Why And How Service Quality Perceptions Impact ConsumerResponses, Managing Service Quality, Vol. 19 No. 4, pp. 474-485

Ghozali. I., 2008, Model Persamaan Struktural, Konsep Dan aplikasi Dengan Program Amos16.0, Badan Penerbit Universitas Diponegoro, Semarang pp. 12 - 98.

Gruber .I., 2011, I want to believe they really care How complaining customers want to be treated by frontline employees, Journal of Service Management, Vol. 22 No. 1, pp. $85-110$

Hinson R , Frimpong O. U dan Dasah. J, 2011, Brands and service-quality perception Marketing Intelligence \& Planning, Vol. 29, No. 3, pp. $264-283$.

http://id.wikipedia.org/wiki/Telekomunikasi

http://id.wikipedia.org/wiki/Telekomunikasi Indonesia

Jamal dan Anastasiadou. K, 2009, Investigating the effects of service quality dimensions and expertise on loyalty, European Journal of Marketing, Vol. 43, No. 3/4, pp. 398 420.

Jane Li. S, Ying Huang. Y, dan Yang. M. M., 2011, How satisfaction modifies the strength of the influence of perceived service quality on behavioral intentions, Leadership in Health Services, Vol. 24, No. 2, pp. $91-105$

Karsono, 2008, Peran Mediasi Kepuasan Pelanggan, Citra Perusahaan dan Biaya Switching Dalam Pengaruh Kualitas Pelayanan Pada Kesetiaan Pelanggan, Fokus Manajerial Jurnal Manajemen dan Kewirausahaan, Vol. 6, No. 2, pp $10-31$.

Kim, G., Wang dan Mattila, 2010., The relationship between consumer complaining behavior and service recovery, An integrative review International Journal of Contemporary Hospitality Management, Vol. 22, No. 7, pp. 975-991.

Kinnear, C.T., and Taylor, 1992, R.J., Alih Bahasa Lamarto Yohanes, Riset Pemasaran, Jilid I, Jakarta, Erlangga pp. $39-37$

Kotler, P., Alih Bahasa A. B susanto, 2000, Manajemen Pemasaran di Indonesia Analisis Perencanaan, Implementasi dan Pengendalian, Buku Satu, Salemba Empat, Jakarta,pp. 19

Kotler, P and Keller, K. L., 2008, Manajemen Pemasaran, Edisi Keduabelas, Jilid 1, PT. Indeks, Indonesia, pp.19- 308

Kotler, P and Keller, K. L., 2008, Manajemen Pemasaran, Edisi Keduabelas, Jilid 2, PT. Indeks, Indonesia, pp. $12-42$ 
Kumar. A dan Lim.H., 2008, Age differences in mobile service perceptions: comparison of Generation $Y$ and baby boomers, Journal of Services Marketing, Volume 22, Number 7, 568-577

Ladhari .R., 2009, Service quality, emotional satisfaction, and behavioural Intentions A study in the hotel industry Managing Service Quality, Vol. 19, No. 3, pp. $308-331$.

Lupiyoadi, R., 2001, Manajemen Pemasaran Jasa Dan Praktik, Edisi Pertama, Salemba empat, Jakarta pp. $6-8,148-150$.

Matos. C. A., 2009, Consumer reaction to service failure and recovery: the moderating role of attitude toward complaining, Brazil Journal of Services Marketing, Vol. 23, Nomor 7, 462-475

Mattila. S.A., 2010, Do women like options more than men? An examination in the context of service recovery, Journal of Services Marketing Volume 24, Number 7, 499-508.

Sandy. N., David. M. E., dan Dagger TS., 2011 Generating positive word of mouth in the service experience, Managing Service Quality, Vol. 21, No. 2, 133-151.

Neira . C. V., Casielles R. V., dan Iglesias. V., 2010, Lack of preferential treatment: effects on dissatisfaction after a service failure, Journal of Service Management,Vol. 21 No. $1, .45-68$

Phau. I., dan Baird. M, 2008, Complainers versus non-complainers retaliatory responses towards service dissatisfactions, Marketing Intelligence \& Planning, Vol. 26 No. 6, 587-604.

Rod. M dan Ashill N.J, 2010, The effect of customer orientationon frontline employees job outcomes in a new public management context United Arab Emirates, Marketing Intelligence\&Planning, Vol. 28, No. 5, 600-624

Rod M, Ashill NJ, Shao dan Carruthers., 2009, An Examination Of The Relationship Between Service Quality Dimensions, Overall Internet Banking Service Quality And Customer Satisfaction, Marketing Intelligence \& Planning, Vol. 27, No. 1, 103-126

Sharma. P., Mathur. R., Dhawan. A., 2009, Exploring customer reactions to offshore call centers: toward a comprehensive conceptual framework, Journal of Services Marketing, Vol. 23, No. 5, 289-300

Sukardi, 2009, Metodelogi Penelitian Pendidikan Kompetensi Dan Praktikya, Cetakan Ketujuh, Bumi Aksara, Jakarta pp.53 Supranto, 1983, Teknik Riset Pemasaran dan Ramalan Penjualan, Ghalia Indonesia, Jakarta, pp. $62-88$.

Supranto, 2001, Pengukuran Tingkat Kepuasan Pelanggan Untuk Menaikkan Pangsa Pasar, Cetakan Kedua, PT. Reinka Cipta, Jakarta, pp. $43-75$

Suyono, J., 2008., Sikap Terhadap Sponsorship Pada Sport Event Dan Music Event, Fokus Manajerial Jurnal Manajemen Dan Kewirausahaan, Vol. 6, No.2, pp. 1-9 
Stanton, W., 1984., Prinsip Pemasaran Diterjemahkan Oleh Sadu Sundaru, Edisi Ketujuh, Jilid 2, Erlangga, Jakarta, pp. $219-236$

Swastha,B. dan Handoko,T.H., 1984, Manajemen Pemasaran Analisa Perilaku Konsumen. Edisi Pertama, Cetakan Kedua, Liberty, Yogyakarta, pp. 58 - 92

Swastha, B. dan Irawan., 1990, Manajemen Pemasaran Modern, Edisi Kedua, Cetakan Kedelapan, Liberty, Yogyakarta, pp. 8

Swanson.S.R, Frankel.R, Sagan. M, Johansen D.L.,2011, Private and public voice: exploring cultural influence, Managing Service Quality, Vol. 21, No. 3, pp. 216- 239.

Tronvoll. B., 2011, Negative emotions and their effect on customer complaint Behavior, Journal of Service Management, Vol. 22, No. 1, pp. 111-134 